\title{
Coffee Fix
}

\section{Hannab McKinnon}

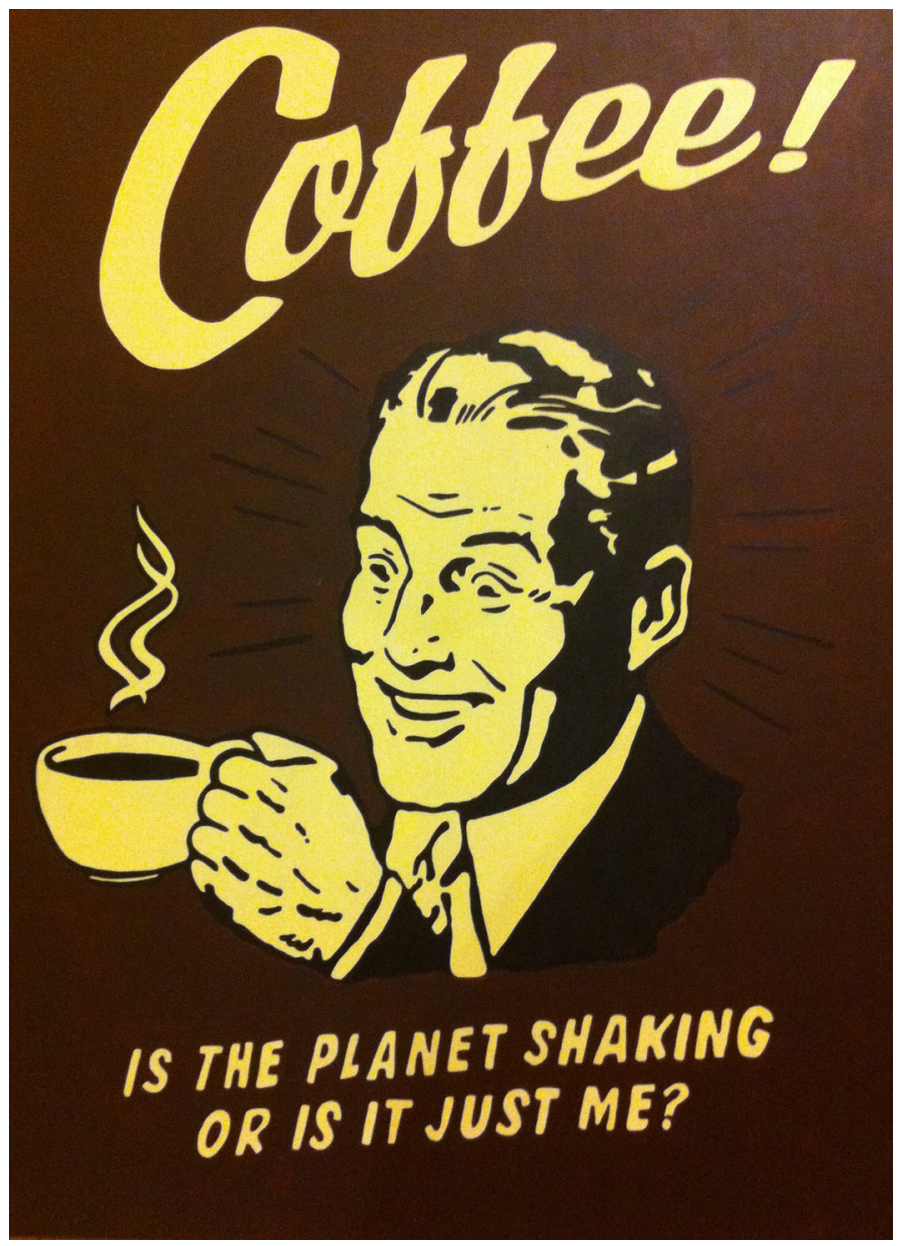

Offset no. 11 | 43 